\title{
Heterosis for hatch weight and body weight gain in outcrossed native chickens of Nigeria under savanna conditions
}

${ }^{1}$ Egahi, J. O., ${ }^{1}$ Momoh, O. M. and ${ }^{2}$ Abang, F. B. P.

${ }^{I}$ Department of Animal Breeding and Physiology,

${ }^{2}$ Department of Animal Production, University of Agriculture Makurdi

Abstract

The normal feathered (NF), frizzle feathered $(F F)$ and naked neck $(N a)$ native chickens of Nigeria were outcrossed under the savanna ecology. Eggs were collected and artificially incubated in electric type incubator. Chicks were weighed at hatch, identified and raised on a standard compounded ration. Body weight increase was evaluated at 4-20 weeks of age. Heterosis was evaluated for hatch weight and body weight at 20 weeks of age. Results revealed that percent heterosis ranged from -12.11 to 1.66 and 1.93 to 12.80 for hatch weight and body weight at 20 weeks of age, respectively. The outcrosses using the NF as males had a higher body weight at 20 weeks of age. Consequently, the environmental limitation on growth impinged more on the NF than on the FF and Na genotypes. It was also noted that there is a greater divergence between the NF and the FF, the NF and Na than between the FF and Na birds. Outcrossing the NF birds with the FF and Na birds in the savanna may therefore improve body weight at 20 weeks of age in the outcrosses than in the respective straight bred genotypes.

Keyword: Normal feather, Frizzle feather, naked neck, outcross

\section{Introduction}

The native chickens of Nigeria occupy a unique niche in the life of rural settlers not only in the Guinea savanna but throughout the country where small populations of the chicken types are found in almost all rural communities. They are quite easy to raise as they perfectly fit into the rural production system where the birds scavenge for most of their nutritional requirements. The Guinea savanna of Nigeria poses no serious threat to the survival of these native birds due to the abundance of scavengeable feed resources from cereals and cereal leftovers after harvest (Egahi et al., 2017). However, they have been rated low in terms of meat and egg output (Egahi et al., 2013) when compared with the exotics. A plausible way of improving these native birds is grading up using exotic males. The previous introduction of exotic cocks in this regard failed for obvious reasons.Outcrossing which is the mating between unrelated individuals within a specie/breed is common practice among the native chickensof Nigeria in the Guinea savanna. Oluyemi (1979) advocated the development of new strains of the indigenous chicken by crossing between indigenous ecotypes as a means of improving the productivity of the local. Thus, it is common knowledge that outcrossing results in heterosis in the offspring. Sheridan (1980) referred to heterosis as the superiority of a crossbred (outcrossed) animal over the average performance of its parents. Sheridan (1981) further explained that heterosis is any favourbale departure from additivity in crossbred populations. Fairfull (1990) treated heterosis as the deviation of the crossbred progeny above the mean performance of their two parents.However, several authors have reported the occurrence of negative heterosis; a situation where the performance of the offspring is below that of the parental mean. Mekki et al. 


\section{Heterosis for hatch weight and body weight gain in outcrossed native chickens of Nigeria}

(2005) reported that the Nigerian local chicken possess a good nicking or specific combining ability which could be used to exploit heterosis. There is a dearth of information on the results of outcrossing involving the Nigerian local chickens in the guinea savanna. The current study was designed to bridge this gap by investigating heterosis for hatch weight and body weight in outcrossed native chickens of Nigeria in the guinea savanna with the aim of improving their productivity through selection.

\section{Materials and methods Experimental site}

The experiment was carried out in Makurdi, Nigeria. The co-ordinates, rainfall pattern, humidity and temperature variations in Makurdi have already been described by Dzungwe (1991).

\section{Experimental design}

The experiment was based on a completely randomized design with six experimental units each replicated thrice to obtain both the main cross and outcrossed offsprings.

Parental population and their management

The parental stock consisted of ninety birds each of the three phenotypic expressions (normal feathered, frizzled feathered, and naked necked) obtained from the local markets within Makurdi and its environs and kept for an adaptation period of four weeks during which they were given prophylactics against common endemic diseases. At the end of the adaptation period, the birds were distributed randomly into breeding pens with a mating ratio of 1:10 cock to hen respectively. The mating arrangement in Table 1 was used to generate the experimental birds. The chicks generated were raised to 20 weeks of age.

Table 1: Mating arrangement for generating outcrossed chicks

\begin{tabular}{clllcl}
\hline Breeding group & Males & Females & Mating ratio & Replications & Genetic group \\
\hline NF X NF & NF & NF & $1: 10$ & 3 & Main cross (1) \\
FF X FF & FF & FF & $1: 10$ & 3 & Main cross (2) \\
Na X Na & Na & Na & $1: 10$ & 3 & Main cross (3) \\
NF X FF & NF & FF & $1: 10$ & 3 & Outcross $(1,2)$ \\
NF X Na & NF & Na & $1: 10$ & 3 & Outcross $(1,3)$ \\
FF X Na & FF & Na & $1: 10$ & 3 & Outcross $(2,3)$ \\
\hline
\end{tabular}

NF-Normal feathered genotype.

FF- Frizzle feathered genotype.

Na- Naked neck genotype

\section{Growth measurements}

Individual weights were taken at 4-weekly intervals from day old to 20 weeks of age using a digital weigh balance. Daily weight gain was calculated using the procedure described by Msofffe et al. (2004)

Daily growth rate $=\underline{\mathrm{W}}_{2}-\mathrm{W}_{1}$

$$
\mathrm{N}
$$

Where: $\mathrm{W}_{1}=$ initial weight.

$\mathrm{W}_{2}=$ final weight.

$\mathrm{N}=$ number of days between measurements.

Heterosis was estimated for growth in the various breeding groups using the principles of Fairfull (1990).

\section{Results and discussion}

Table 2 presents the hatch weight in the genetic groups. Mean hatch weights ranged from $25.76 \pm 0.43 \mathrm{~g}$ to $31.13 \pm 0.43 \mathrm{~g}$ for the $\mathrm{Na} x \mathrm{NF}$ and $\mathrm{Na} x \mathrm{Na}$, respectively. Hatch weight varied significantly $(\mathrm{p}<0.05)$ between the main and the outcrossed genotypes. In general, hatch weight was dependent on egg size. Heavier females lay weightier eggs and consequently have higher weight of chicks at hatch than smaller bodied females. Outcrossing the $\mathrm{NF}$ by the $\mathrm{FF}$ and $\mathrm{Na}$ genotypes did not result in significant differences in hatch weight between the outcross and main cross 


\section{Egahi, Momoh and Abang}

genotypes. Outcrossing however, significantly $(\mathrm{P}<0.05)$ improved the hatch weight of the $\mathrm{Na} x \mathrm{FF}$ crosses over the respective main cross genotypes.

Table 2: L east squares means \pm sem of hatch weight $(\mathrm{g})$ in the genetic groups of the nigerian local chicken

\begin{tabular}{lllll}
\hline Breeding group & $\begin{array}{l}\text { No.of } \\
\text { observation }(\mathrm{n})\end{array}$ & Minimum & Maximum & Hatch weight \\
\hline NF x NF & 87 & 21.89 & 35.91 & $26.86 \pm 0.51^{\text {cd }}$ \\
FF x FF & 75 & 19.80 & 35.91 & $27.10 \pm 0.33^{\mathrm{c}}$ \\
$\mathrm{Na} \times \mathrm{Na}$ & 73 & 24.84 & 36.02 & $31.13 \pm 0.43^{\mathrm{a}}$ \\
$\mathrm{NF}$ x FF & 60 & 19.06 & 31.87 & $25.86 \pm 0.40^{\mathrm{d}}$ \\
$\mathrm{NF}$ x Na & 78 & 22.38 & 29.39 & $26.10 \pm 0.19^{\mathrm{d}}$ \\
FF x Na & 88 & 24.30 & 36.02 & $28.61 \pm 0.34^{\mathrm{b}}$ \\
\hline \multicolumn{4}{l}{ a,b,c...within the same column having different superscript are significantly different (P<0.05). } \\
NF-Normal feathered genotype. \\
FF- Frizzle feathered genotype. \\
Na- Naked neck genotype
\end{tabular}

Table 3 presents the mean body weights in the main cross and outcrossed genotypes. Body weights at 20 weeks of age varied significantly between the genetic groups. Heterosis for hatch weight and body weights at 20 weeks of age are respectively presented in Tables 4 and 5. Percent heterosis for hatch weight ranged from 12.11 to 1.66 . The lower end for heterosis observed in the current study for crosses of $\mathrm{NF}$ and $\mathrm{Na}$ was corroborated by the report of Bowman, (1974) that sometimes, the mean performance of the crossbreds may be lower than the mean of the parents. This he referred to as negative heterosis. Heterosis for body weight at 20 weeks of age ranged from 1.93 in the Na outcross to 12.18 in the NF outcross. The values for heterosis for body weight at 20 weeks of age revealed a greater divergence between the normal feather and naked neck than the frizzle feather. Sheridan (1981) reported that the level of expression of heterosis depends on the relationship between the parents.
According to this author, heterosistends to increase as the degree of relationship between the parental lines decreases. Furthermore, Fairfull (1990) in his study concluded that generally, heterosis increased with increasing severity of the environment. It can therefore be inferred that the limitation on growth imposed by the stressing nature of the tropical environment impinges more on the normal feather birds than on the other genetic groups. Consequently, outcrosses of normal feather birds will exhibit higher weight at 20 weeks of age under the prevailing environmental conditions. This could form a viable breeding option for developing fast growing birds for the tropics. Cahaner et al. (1994) recommended that breeding for improved adaptation to particular stressful environment should be the strategy when genotype by environment interaction significantly affects economically important traits. 
Heterosis for hatch weight and body weight gain in outcrossed native chickens of Nigeria

Table 3: Least square means \pm sem of body weight $(\mathrm{g})$ at 20 weeks of age in the genetic groups

\begin{tabular}{ll}
\hline $\begin{array}{l}\text { Breeding } \\
\text { group }\end{array}$ & $\begin{array}{l}\text { Body } \\
\text { weight }\end{array}$ \\
\hline $\mathrm{NF} x$ & $921.14 \pm$ \\
$\mathrm{NF}$ & $4.62^{\mathrm{d}}$ \\
$\mathrm{FF} \mathrm{x}$ & $966.98 \pm$ \\
$\mathrm{FF}$ & $9.14^{\mathrm{c}}$ \\
$\mathrm{Nax}$ & 1047.45 \\
$\mathrm{Na}$ & $\pm 13.88^{\mathrm{b}}$ \\
$\mathrm{NF} x$ & 1040.52 \\
$\mathrm{FF}$ & $\pm 12.34^{\mathrm{b}}$ \\
$\mathrm{NF} x$ & 1088.20 \\
$\mathrm{Na}$ & $\pm 12.21^{\mathrm{a}}$ \\
$\mathrm{FF} x$ & 1040.49 \\
$\mathrm{Na}$ & $\pm 13.06^{\mathrm{b}}$ \\
NF-Normal feathered genotype. & \\
FF- Frizzle feathered genotype. & \\
Na- Naked neck genotype &
\end{tabular}

Table 4: Percent heterosis for hatch weight in the genetic groups of the Nigerian local chicken

\begin{tabular}{crrrr}
\hline Genotype $\begin{array}{l}\text { Mean hatch wt. (g) } \\
\text { of }\end{array}$ & $\begin{array}{l}\text { Mean hatch } \\
\text { wt. (g) of } \\
\text { putcross }\end{array}$ & $\begin{array}{l}\text { Hatch weight } \\
\text { advantage of outcross }\end{array}$ & $\begin{array}{l}\text { Percentage heterosis.for } \\
\text { hatch weight in outcross }\end{array}$ \\
\hline 1 & 26.86 & 25.98 & -0.88 & -3.28 \\
2 & 27.10 & 27.55 & +0.45 & 1.66 \\
3 & 31.13 & 27.36 & -3.77 & -12.11 \\
\hline
\end{tabular}

$1=$ Normal feathered

2= Frizzle feathered

$3=$ Naked neck

Table 5: Heterosis for body weights at hatch and 20 weeks of age in the genetic groups of the Nigerian local chicken

\begin{tabular}{cllll}
\hline Genotype & $\begin{array}{l}\text { Mean 20 wk wt.(g) } \\
\text { of pure breed }\end{array}$ & $\begin{array}{l}\text { Mean 20 wkwt. } \\
\text { (g) of pure } \\
\text { breed }\end{array}$ & $\begin{array}{l}\text { Mean advantage of } \\
\text { cross breed at 20 } \\
\text { wk wt.(g) }\end{array}$ & $\begin{array}{l}\text { Percentage heterosis } \\
\text { for wt at 20 wk }\end{array}$ \\
\hline 1 & 921.14 & 1033.37 & 112.23 & 12.18 \\
2 & 966.98 & 1064.36 & 97.38 & 10.07 \\
3 & 1047.45 & 1067.71 & 20.26 & 1.93 \\
\hline
\end{tabular}

$1=$ Normal feathered

2= Frizzle feathered

$3=$ Naked neck

\section{Conclusion}

The study showed that outcrossing the Nigerian local chicken led to heterosis for body weight. At 20 weeks of age, this heterosis was more pronounced in outcrosses involving the normal feather birds as the males. It can therefore be recommended that the normal feather males should be used in outcrosses for enhanced or better body weight at 20 weeks of age.

\section{References}

Dzungwe, T. A. 1991. The search for a viable Benue State.Benue State Gazette.pp.13-13. 
Egahi, J. O., Dim, N. I. and Momoh, O. M. 2013. Crossbreeding and reciprocal effect on egg weight, hatch weight and growth pattern and inter relationships between these traits in three genetic groups of native chickens of Nigeria. Pakistan Journal of Biological Sciences 6 (3): 187-191

Egahi, J. O., Abang, F. B. P. and Ochefu, J. 2017. Fertility, hatchability and hatch weight in the native chickens of the savanna region of Nigeria Proceedings of 6th ASAN-NIAS Joint Annual Conference. September 10-14, 2017. Abuja :285-287

Fairfull R. W. and Gowe, R. S. 1990. Genetics of egg production in chickens. In: poultry breeding and Genetics. Ed. Grawford, R. D. Amsterdam. The Netherlands Elsevier Science Publishers B. V. pp.706-759

MekkiDafaalla, M., YousifIbrahimm, A., Abdel Rahman, M. K., Wang, J. Y. and Musa, H. H. 2005. Growth performance of indigenous $\mathrm{x}$ exotic crosses of chicken and evaluation of general and specific combining ability under Sudan condition. Int. J. Poult. Sci., 4.pp.468-471.
Msoffe, P. L. M., Mtambo, M. M. A., Minga, U. M., Olsen, J. E., JuulMadsen, H. R., Gwakisa, P. S., Mutayoba, S. K. and Katule, A. M. 2004. Productivity and reproductive performance ofthe free-range local domestic fowl ecotypes in Tanzania. Livestock Research for Rural Development 16(9) 2004

Oluyemi, J. A. 1979. Potentials of the indigenous species of poultry for meat and egg production in Nigéria. In: Proceedings 1st national Seminar on Poultry Production in Nigéria, Ahmadu Bello University, Zaria, December 11-13. National Animal Production Research Institute.pp.163-186.

Sheridan, A. K. 1980. A new explanation for egg production heterosis in crosses between White Leghorns and Australorps.Brit.Poult.Sci. 21.pp. $85-88$

Sheridan, A. K. 1981. Crossing breeding and heterosis.Anim. Breed Abstr.49(3).pp. 131-141

Received: $4^{\text {th }}$ November, 2017

Accepted: $21^{\text {st }}$ February, 2018 